\title{
Membangun Aplikasi Pencarian Judul LTA dan Skripsi Fakultas Ilmu Komputer Universitas Dehasen Bengkulu
}

\author{
Achmad Fikri Salaby ${ }^{1}$, Merti ${ }^{2}$ \\ ${ }^{1,2}$ Program Studi Sistem Informasi, Universitas Dehasen Bengkulu \\ Email : fikrisalaby@gmail.com
}

\begin{abstract}
The method for searching Final Project Report and Thesis available in study program and faculty are still manually, by opening the file and submission form titles collected in Prodi or study program. Because of that, Information Systems for Thesis Title Search at the Faculty of Computer Science is required to be managed more effectively and more efficiently. It is well to improve performance, especially at the Dehasen University submission of thesis title information from manual to computerized. Hence, in the data processing thesis title will not be the same title, had never been there before, and can facilitate data presentation information. To overcome these problems need to be made a special program of "Apps Search Title Final Project Report and the Faculty of Computer Science Thesis Universitas Dehasen Bengkulu" because this program has a good ability to process information systems effectively and efficiently and can be done online. Keywords: Application Search, Title Thesis, Study Program
\end{abstract}

Intisari-Metode pencarian judul Laporan Tugas Akhir dan Skripsi selamaini yang dilakukan oleh pihak program studi dan fakultas masih secara manual, yaitu dengan cara membuka berkas dan formuli rpengajuan judul yang dikumpulkan di Prodi atau Program Studi. Karena hal-hal tersebut di atas maka Sistem Informasi Pencarian Judul Skripsi Pada Fakultas Ilmu Komputer ini dituntut untuk dikelola dengan lebih efektif dan lebih efisien. Hal ini sekaligus untuk meningkatkan kinerja Universitas Dehasen khususnya pada informasi pengajuan judul skripsi dari manual ke komputerisasi. Sehingga di dalam pengolahan data judul skripsi tidak akan ada judul yang sama dan sudah pernah ada sebelumnya dan dapat mempermudah penyajian data informasi yang ada. Untuk mengatasi masalah tersebut perlu dibuat program khusus yakni "Aplikasi Pencarian Judul Laporan Tugas Akhir (LTA) dan Skripsi Fakultas Ilmu Komputer Universiitas Dehasen Bengkulu" karena program ini memiliki kemampuan cukup baik dalam proses sistem informasi yang efektif dan efisien dan bisa dilakukan secara online.

Kata kunci : Aplikasi Pencarian, Judul Skripsi, Program Studi

\section{PENDAHULUAN}

Perkembangan ilmu pengetahuan teknologi dan informasi pada zaman sekarang, komputer merupakan salah satu teknologi yang sangat dibutuhkan oleh manusia terutama dibidang sistem informasi. Karena dengan komputer informasi mudah didapat dengan cepat dan akurat. Maka dari itu keberhasilan suatu instansi selain didukung oleh sarana dan prasarana haruslah didukung dengan sistem yang ada di dalam instansi tersebut, perlu diingat bahwa kemampuan manusia sangat terbatas sehingga manusia membutuhkan peralatan yang dirancang sedemikian rupa.

Teknologi internet bukan lagi menjadi kalimat yang asing bagi orang yang berkecimpung didunia komputer. Tidak heran jika banyak sekali kita jumpai tempat-tempat untuk mengakses internet. Bukan hanya itu, bahkan di kalangan perusahaan, instansi pemerintah dan lingkungan pendidikan seperti sekolah Universitas, kini telah membuka akses untuk layanan internet. Antara sesama pemakai internet, berkomunikasi dengan cara mengirim dan menerima pesan. Selain itu, fasilitas internet juga memberikan pengambilan file-file program secara gratis. Tentu saja ini menjadikan internet sebagai media atau sarana informasi dan teknologi yang terpercaya dan tercepat bagi masyarakat dunia saat ini.

Metode pencarian judul Laporan Tugas Akhir dan Skripsi selama ini yang dilakukan oleh pihak program studi dan fakultas masih secara manual, yaitu dengan cara membuka berkas dan formulir pengajuan judul yang dikumpulkan di Prodi atau Program Studi. Karena hal-hal tersebut di atas maka Sistem Informasi Pencarian Judul Skripsi Pada Fakultas Ilmu Komputer ini dituntut untuk 
dikelola dengan lebih efektif dan lebih efisien. Hal ini sekaligus untuk meningkatkan kinerja Universitas Dehasen khususnya pada informasi pengajuan judul skripsi dari manual ke komputerisasi. Sehingga di dalam pengolahan data judul skripsi tidak akan ada judul yang sama dan sudah pernah ada sebelumnya dan dapat mempermudah penyajian data informasi yang ada.

Untuk mengatasi masalah tersebut perlu dibuat program khusus yakni Aplikasi Pencarian Judul Laporan Tugas Akhir (LTA) Skripsi Fakultas Ilmu Komputer Universiitas Dehasen Bengkulu karena program ini memiliki kemampuan cukup baik dalam proses sistem informasi yang efektif dan efisien dan bisa dilakukan secara online.

Adapun rumusan masalah dalam penelitian ini adalah Bagaimana membuat Aplikasi Pencarian Judul LTA dan Skripsi Pada Fakultas Ilmu Komputer Universitas Dehasen Bengkulu?

\section{LANDASAN TEORI}

\section{A. Pengertian Sistem Informasi}

Menurut Jogiyanto (2005 : 34), menyatakan bahwa sistem adalah kumpulan dari komponenkomponen yang saling berhubungan satu dengan yang lainnya membentuk satu kesatuan untuk mencapai tujuan tertentu. Contoh sistem yang didefinisikan dengan pendekatan komponen adalah sistem komputer yang di definisikan sebagai kumpulan dari perangkat keras dan perangkat lunak.

Suatu sistem harus mempunyai sasaran, karena sasaran sangat menentukan sekali masukan yang dibutuhkan sistem dan keluaran yang akan dihasilkan sistem. Suatu sistem dikatakan berhasil bila mengenai sasaran atau tujuannya (Jogiyanto, $2005: 54)$.

Informasi menurut Whitten (2004 : 27) adalah data yang telah diproses atau disusun kedalam suatu format sehingga lebih berarti untuk seseorang. Informasi dibentuk dari kombinasi dari data yang dengan penuh harapan dapat mempunyai arti bagi penerimaan. Informasi harus bebas dari kesalahankesalahan dan tidak biasa atau menyesatkan, dan harus jelas mencerminkan maksudnya. Ketidakakuratan dapat terjadi karena sumber informasi (data) mengalami gangguan atau kesenjangan sehingga merusak atau merubah data-data asli tersebut.

Whitten (2004: 12) mendefinisikan sistem informasi sebagai suatu susunan dari orang, data, proses dan teknologi informasi yang saling berhubungan untuk mengumpulkan, memproses, menyimpan dan menyediakan keluaran informasi yang diperlukan untuk mendukung suatu organisasi.

Sistem Informasi mempunyai enam buah komponen (Jogianto, $2005: 42$ ) yaitu :

\section{1) Komponen Input}

Input merupakan data yang masuk kedalaman sistem Informasi. Komponen ini perlu ada karena merupakan bahan dasar dalam pengolahan Informasi. Sistem Informasi tidak akan dapat menghasilkan Informasi jika tidak mempunyai komponen input.

\section{2) Komponen Model}

Informasi dihasilkan oleh sistem informasi berasal dari data yang diambil dari basis data yang diolah lewat suatu model-model tertentu.

\section{3) Komponen Output}

Produk dari sistem informasi adalah output. Berupa informasi yang berguna bagi para pemakainya. Output. Berupa informasi yang berguan bagi pemakainya. Output merupakan komponen yang harus ada di sistem informasi. Output dari sistem informasi di buat dengan menggunakan data yang ada masih di diproses menggunakan model yang tertentu.

\section{4) Komponen Teknologi}

Teknologi merupakan komponen yang penting di sistem informasi dibuat dengan menggunakan data yang ada di basis data dan di proses menggunakan model yang tertentu.

\section{5) Komponen Basis Data}

Basis Data (database) adalah kumpulan dari 
data yang saling berhubungan satu sama lainnya, tersimpan diperangkat keras komputer dan digunakan perangkat lunak untuk memanipulasinya.

\section{6) Komponen Kontrol atau Pengendalian}

Komponen Kontrol juga merupakan komponen yang penting dan harus ada disistem informasi. Komponen kontrol digunakan untuk menjamin bahwa informasi yang dihasilkan oleh sistem informasi merupakan informasi yang akurat.

\section{B. Konsep Dasar Aplikasi}

Menurut Jogiyanto (2005:4), aplikasi merupakan program yang berisikan perintah-perintah untuk melakukan pengolahan data. Jogiyanto menambahkan aplikasi secara umum adalah suatu proses dari cara manual yang ditransformasikan ke komputer dengan membuat sistem atau program agar data diolah lebih berdaya guna secara optimal. Menurut kamus komputer eksekutif, pengertian aplikasi merupakan pemecahan masalah yang biasanya berpacu pada sebuah komputasi yang diinginkan atau diharapkan maupun pemrosesan data yang diharapkan. Aplikasi biasanya berupa perangkat lunak yang berbentuk software yang berisi kesatuan perintah atau program yang dibuat untuk melaksanakan sebuah pekerjaan yang diinginkan. Selain itu aplikasi juga mempunyai fungsi sebagai pelayan kebutuhan beberapa aktivitas yang dilakukan oleh manusia seperti sistem untuk software jual beli, permaian atau game online, pelayanan masyarakat dan hampir semua proses yang dilakukan oleh manusia dapat dibantu dengan menggunakan suatu aplikasi. Lebih dari satu aplikasi jika digabungkan akan menjadi satu paket atau sering juga disebut dengan application suite, dimana aplikasi tersebut memiliki posisi antar muka yang mempunyai kesamaan sehingga dapat dengan mudah digunakan atau dipelajari penggunaan tiap aplikasi tersebut.

\section{Sistem Komputer}

\section{1) Tinjauan Umum Perangkat Lunak (Softwa-} re)

Perangkat lunak (Software) adalah suatu pe- rangkat lunak yang berisi serangkaian intruksi, program, prosedur, pendukung, dan aktivitas pengolahan perintah pada sistem komputer. Perangkat lunak dapat dikelompokan menjadi tiga yaitu :

a) Sistem Operasi, merupakan Software yang berfungsi melakukan operasi yang mengurusi tentang aktivitas komputer seperti mendukung operasi sistem dan mengendalikan semua perangkat komputer agar dapat berjalan selaras dengan fungsinya. Yaitu seperti: Windows, Linux, Unix dan sebagainya.

b) Program Aplikasi, merupakan software yang sudah siap di pakai untuk menyelsaikan pekerjaan-pekerjaan tertentu, misalnya untuk membuat dokumen, manipulasi foto atau membuat laporan keuangan. Contohnya : Microsoft Word dan Microsoft Excel dan sebagainya.

c) Bahasa pemrograman, adalah software bahasa yang digunakan dengan cara merancang atau membuat program sesuai dengan struktur dan metode yang dimiliki oleh bahasa program itu sendiri.

\section{2) Tinjauan Umum Perangkat Keras (Hardwa- re)}

Menurut Kumorotomo (2000 : 19) perangkat keras menuju kepada perangkat mesin. Perangkat keras (Hardware) merupakan segala sesuatu yang bersifat fisik, yaitu komputer itu sendiri sebagai benda. Perangkat keras itu sendiri sebagai benda. Perangkat keras terdiri atas 4 kelompok, yaitu :

a) Perangkat masukan (Input Device), merupakan bagian yang berfungsi untuk membaca dari media pembaca data, misalnya : keyboard, mouse, joystick, scanner dan sebagainya.

Perangkat keluaran (Output Device), merupakan bagian yang berfungsi sebagai keluaran dari pengolahan data. Bagian keluaran dibedakan menjadi dua yaitu hard-copy dan soft-copy. Hardcopy adalah hasil cetakan pada media cetak, biasanya berupa kertas, contohnya printer, faksimile dan lain-lain. Soft-copy adalah hasil cetakan yang tersimpan dalam komputer atau media penyim- 
panan eksternal lannya dan dapat diakses jika diperlukan, contohnya monitor.

CPU (Central Processing Unit), merupakan bagian dari komputer yang fungsinya untuk memproses data.

Unit Penyimpanan Data, merupakan bagian dari perangkat keras yang fungsinya sebagai penyimpanan data. Penyimpanan data dapat dilakukan di dalam main memori komputer maupun didalam media penyimpanan eksternal. Memori utama (Main Memory) adalah media penyimpanan yang diakses langsung oleh CPU. Di dalam memori umumnya di indentikan dengan Random Accses Memory (RAM).

\section{3) Pemakai (Brainware)}

Brainware disini diartikan sebagai manusia berperan atau berinteraksi langsung dengan komputer, tanpa manusia komputer tidak dapat dijalankan.

\section{Metode Pengembangan Sistem}

Perancangan suatu sistem informasi berdasarkan rekayasa informasi adalah satu sumber dari proyek pengembangan basis data. Beberapa proyek melakukan pengembangan basis data atau sistem informasi guna memenuhi kebutuhan strategis organisasi. Menurut Nugroho (2004:40), metode pengembangan sistem yang sering dipakai oleh organisasi adalah metode RAD (Rapid Application Development) yang mengikuti proses interaktif dari tahap-tahap analisis, perancangan, serta implementasi hingga mendapatkan sistem yang memang dikehendaki pengguna. Secara definitif RAD merupakan Systems Development Life Cycle (SDLC) dengan memanfaatkan komponen yang sudah ada yang dapat digunakan ulang (Reusable Component).

Salah satu metode yang populer dalam $R A D$ adalah prototyping. Prototyping adalah proses pengembangan sistem secara literatif dimana kebutuhan pengguna dikonversi ke sistem yang sedang berjalan secara kontinue diperbaiki dengan kerjasama antara analisis dan pengguna. Selama pengembangan dari prototype awal, kita secara simultan merancang tampilan-tampilan dan laporan yang dikehendaki pengguna dan merancang kebutuhan setiap basis data yang diperlukan dan mendefinisikan basis data yang digunakan oleh prototype. Ini secara tipikal merupakan basis data baru yang merupakan salinan dari sebagian basis data yang telah ada (kemungkinan dengan isi yang baru). Jika isi yang baru dibutuhkan, mereka umumnya datang dari sumber data eksternal seperti hasil riset pasar, indikator ekonomi secara umum, serta standar industry.

Mengulang implementasi basis data dan aktivitas pemeliharaan sebagai versi baru dari prototype yang dihasilkan. Sering kali kendali keamanan dan integritas sangat minimal sebab penekanannya adalah menghasilkan prototype sesegera mungkin dan dokumentasi cenderung ditunda hingga akhir dari proyek. Terakhir, saat prototype yang dapat diterima tercipta, analisis dan pengguna memutuskan prototype final (dan basis datanya). Jika sistem (termasuk basis datanya) sangat tidak efisien, sistem dan basis data dirancangulang dan direorganisasi hingga mencapai kinerja yang dapat diterima.

\section{E. Konsep Perancangan Data Base}

Menurut Ladjamudin (2005:62), Konsep dan Implementasi dari sistem basis data dalam suatu proyek pengembangan sistem informasi, sehingga tidak terpaku pada definisi dari sistem basis data. Merancang data base merupakan hal yang sangat penting, perancangan data base merupakan kombinasi berbagai proses aplikasi. Penulis menggunakan pemodelan data sebagai berikut:

\section{1) Diagram Alir Data (DAD)}

Data flow diagram adalah gambaran sistem logikal, gambaran ini tidak tergantung pada perangkat keras, perangkat lunak, struktur. Keuntungan DAD adalah memudahkan user mengusai dan mengetahui sistem komputer yang dikerjakan. Beberapa symbol digunakan dalam DAD adalah :

a) External Entity (kesatuan luar). Sistem yang mempunyai batas yang memisahkan sistem 
dengan lingkungan luar, sistem akan menerima masukkan dan menghasilkan keluaran pada lingkungan luar.

b) Data Flow (Arus Data). Arus data ini mengalir diantara proses, simpan data, dan kesatuan luar, arus data ini menunjukan arus data yang dapat berupa masukkan untuk sistem atau hasil dari sistem.

c) Process (Proses). Proses adalah kegiatan yang dilakukan orang, mesin, atau komputer dari hasil arus data yang masuk dalam proses untuk dihasilkan dari sistem.

d) Data Store (Simpanan Data). Simpanan data adalah suatu media penyimpan data, yang terkomputerisasi maupun yang tidak terkomputerisasi.

\section{2) Entity Relationship Diagram (ERD)}

Menurut Herlambang dan Tanuwijaya (2005:203) ERD merupakan suatu model untuk menjelaskan hubungan antar data dalam basis data, berdasarkan suatu persepsi bahwa real word terdiri dari objek dasar yang mempunyai hubungan atau relasi antar objek. Model entity relationship adalah suatu penyajian data dengan menggunakan entity dan relationship.

\section{3) Hierarkiplus Input Process Output (HIPO)}

Menurut Ladjamudin (2005:218) Hierarkiplus Input Process Output (HIPO) merupakan teknik untuk mendokumentasikan sistem pemograman. HIPO dikembangkan oleh personal IBM yang percaya bahwa dokumentasi sistem pemograman yang dibentuk dengan menekankan pada fungsi. HIPO menyediakan fasilitas lokasi dalam bentuk kode dari tiap prosedur dalam suatu sistem.

\section{METODE PENELITIAN}

\section{A. Tempat dan Waktu Penelitian}

Dalam Pengumpulan data pembuatan Proposal Skripsi ini penulis melaksanakan pra penelitian dan penelitian pada Prodi Sistem Informasi
Fakultas Ilmu Komputer Universitas Dehasen yang terletak di Jalan Meranti Raya No.32 Kota Bengkulu Telp (0736) 22027 Kota Bengkulu. Penelitian dilaksanakan bulan Desember 2016.

\section{B. Metode Penelitian}

Adapun metode penelitian ini menggunkan Metode Pengembangan yaitu bagaimana program dikembangkan Pada Fakultas Ilmu Komputer Universitas Dehasen pengolahan datanya sudah menggunakan program Microsoft Word dan Microsoft Exel, namun belum dapat memberikan hasil yang maksimal dan membutuhkan waktu yang lama dalam hal pemberian informasi. Maka dari itu program ini dikembangkan oleh penulis agar dapat membantu kelancaran proses pengolahan data sistem informasi pencarian judul skripsi.

\section{Software Dan Hardware}

Guna untuk mendukung penelitian ini maka software yang digunakan penulis untuk mendukung pembuatan sistem informasi ini adalah:

1. Sistem Operasi Windows 7

2. Mozilla Firefox

3. Program Aplikasi yang digunakan Bahasa pemrograman $P H P$ dan $M y S Q L$.

Hardware yang digunakan penulis adalah komputer dengan spesifikasi sebagai berikut :

1. Pentium IV 3 Gh

2. Memory $(R A M)$ SDR $256 \mathrm{MB}$

3. Monitor 11 inchi

4. Printer Canon iP 2770

\section{Metode Pengumpulan Data}

Untuk memperoleh data yang diperlukan dalam penelitian ini penulis menggunakan beberapa metode dalam pengumpulan data yaitu:

\section{1) Metode Observasi}

Merupakan metode pengumpulan data yang digunakan dengan cara melakukan pengamatan langsung pada objek yang diteliti, mengumpulkan dokumen input yang berhubungan dengan sistem informasi pencarian judul skripsi Fakultas Ilmu Komputer di Universitas Dehasen kota 
Bengkulu.

\section{2) Metode Studi Pustaka}

Merupakan metode pengumpulan data yang dilakukan dengan cara membaca buku-buku yang berhubungan dengan masalah yang dibahas dalam penelitian ini.

\section{3) Metode Wawancara}

Merupakan metode wawancara yang dilakukan dengan cara tanya jawab langsung dengan beberapa sekretaris dan staf fakultas ilmu komputer guna untuk mendapatkan data yang ada hubungannya dengan masalah yang dibahas dalam penelitian ini.

\section{E. Metode Perancangan Sistem}

\section{1) Analisa Sistem Aktual}

Sistem komputer yang digunakan dalam mengolah informasi judul skripsi masih menggunakan Microsoft Word dan Exel. Sedangkan hal-hal yang berhubungan dengan penyampaian informasi dilakukan melalui surat dan memasang pengumuman yang di tempel pada Mading Universitas Dehasen, yang tentu menjadi kendala bagi mahasiswa/wi yang berada di luar kota Bengkulu yang bermaksud mengajukan judul LTA atau Skripsi tentu harus mendapatkan referensi terkait dengan judul yang sudah pernah diajukan sebelumnya di Fakultas Ilmu Komputer Unived Bengkulu, mengingat jarak yang cukup jauh maka informasi yang diterima kadang tidak tepat pada waktunya dapat memakan waktu yang lama dan biaya yang tidak sedikit. Oleh karena itulah diperlukan penyampaian informasi yang terkomputerisasi secara online yang dituangkan dalam bentuk website demi tercapainya tujuan yang diinginkan.

Berdasarkan pengamatan yang dilakukan di Universitas Dehasen Kota Bengkulu khususnya pada Fakultas Ilmu Komputer masih belum efektif dan efisien serta belum memberikan hasil akan kebutuhan informasi yang maksimal. Maka melalui penelitian ini akan di rancang dan dibuat sebuah website, dimana data dan informasi yang berhubungan dengan pencarian judul skripsi khu- susnya pada Fakultas Ilmu Komputer dapat di sajikan secara cepat dan online serta dapat diakses oleh mahasiswa/wi kapan pun dan dimana pun. Dimana sistem ini nantinya akan didesain menggunakan bahasa pemrograman PHP MySQL.

\section{2) Analisa Sistem Baru}

Pada sistem baru ini akan dirancang sistem informasi pencarian judul skripsi dengan menggunakan sistem komputerisasi, dengan komputerisasi memungkinkan pemberian informasi dan pengolahan data yang lebih cepat dan mudah dalam pencarian data yang diinginkan sewaktu-waktu. Sistem informasi pencarian judul ini menggunakan pemrograman PHP MySQL.

\section{3) Rancangan Pengujian}

Pengujian adalah proses eksekusi suatu program dengan maksud menemukan kesalahan Rancangan pengujian yang dilakukan menggunakan metode berikut ini.

a) Pengujian Offline, dilakukan secara offline menggunakan server local (localhost). Untuk melakukan pengujian local digunakan software WAMP Server dan Web Broser, misalnya Mozilla Firefox. Pengujian dengan cara mengetikan http://localhost/nama_web.Pengujian offline akan melihat hasil website sebelum di upload ke web server online. Pada pengujian offline akan terlihat hasil tampilan dari masing-masing menu.

b) Pengujian Online, dilakukan setelah pengujian secara offline di komputer localhost tidak mengalami masalah. Setelah seluruh data di upload ke web server, dilakukan pengujian dengan mengetikkan alamat website yang telah didaftarkan pada penyedia domain ke software web browser.

c) Pengujian Alpha, dilakukan dengan menggunakan metode black box. Untuk pengujian alpha ini yaitu pada pengujian sebagai pengguna. Beberapa hal yang diuji pada pengujian ini adalah pengujian login, pengujian pengolahan data (penambahan data, pengeditan data dan penghapusan data) dan pengujian hasil pengolahan data 
dapat ditampilkan sesuai dengan output yang diharapkan.

\section{HASIL DAN PEMBAHASAN}

Aplikasi ini telah berhasi dibangun sesuai dengan kebutuhan yang diperlukan oleh sistem, sehingga aplikasi ini diharapkan mampu menunjang dan membantu pihak yang terkait dalam proses pengolahan data dan menghasilkan informasi yang cepat, efektif dan akurat.

\section{A. Tampilan Menu Login}

Pada tampilan ini digunakan sebagai akses masuk kedalam sistem untuk dapat mengolah data.Tampilan Menu login dapat dilihat pada Gambar 1.

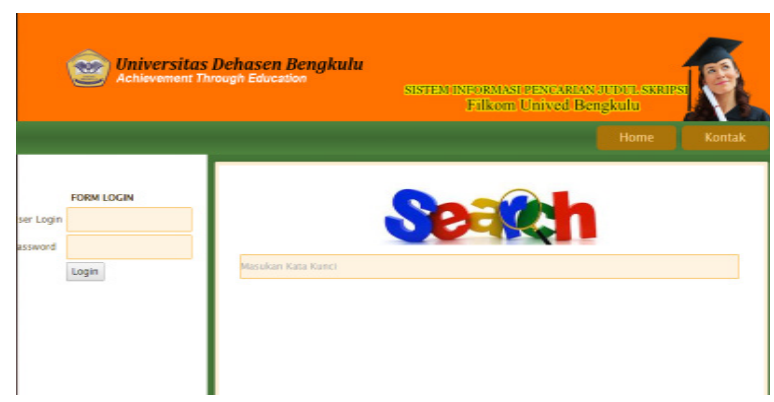

Gambar 1. Tampilan Menu Login

\section{B. Tampilan Menu Utama}

Didalam Menu Utama terdapat deretan Struktur Menu yang mana terdiri dari Menu Kategori, Periode, Prodi, Judul, Judul, Pembimbing, Penguji, Mahasiswa, Laporan, User dan Logout terdapat juga Menu Home dan Kontak. Tampilan pada Menu Utama dapat dilihat pada Gambar 2.

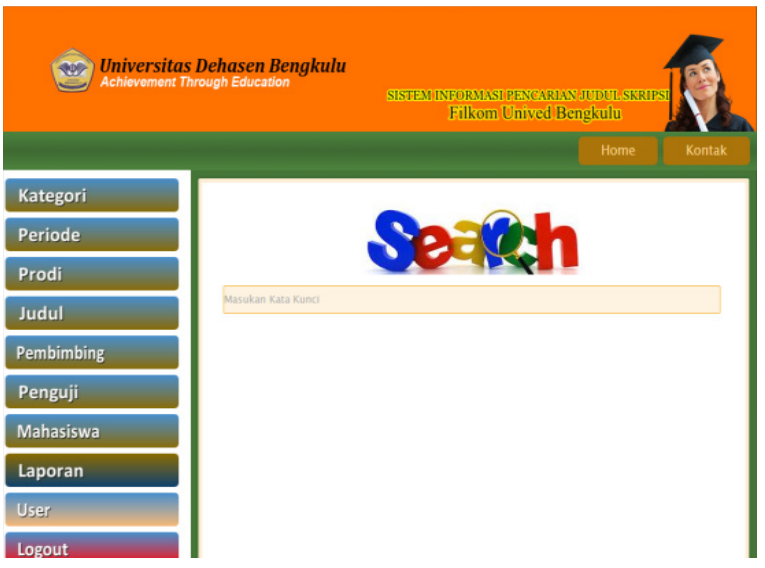

Gambar 2. Tampilan Menu Utama

\section{Tampilan Menu Data Kategori}

Pada menu Kategori terdapat pilihan kategori judul skripsi yang ingin diinputkan. Misalnya kategori Sistem Informasi, Aplikasi, e-Learning, Sistem Pakar dan lain-lain. Tampilan menu kategori seperti terlihat pada Gambar 3.

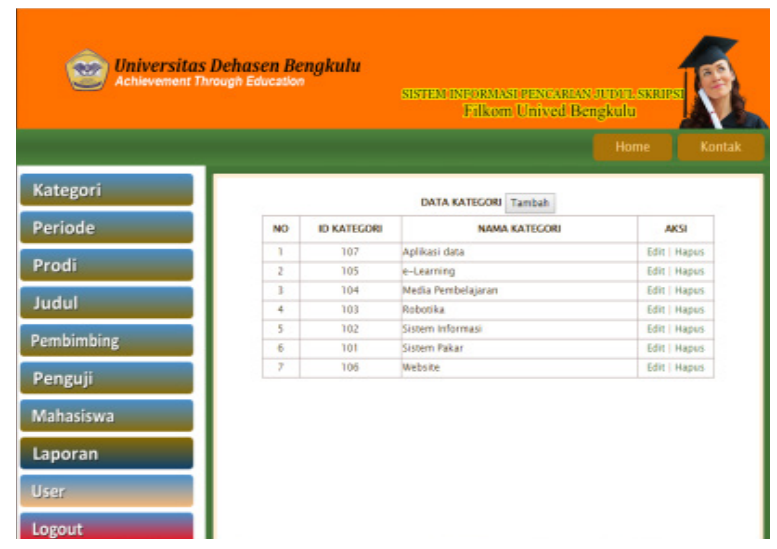

Gambar 3. Tampilan Menu Data Kategori

\section{Tampilan Menu Data Periode}

Pada menu Data Periode terdapat dua pilihan periode wisuda yaitu Periode Ganjil dan Genap pada setiap tahunnya. Tampilan menu data Periode dapat dilihat pada Gambar 4.

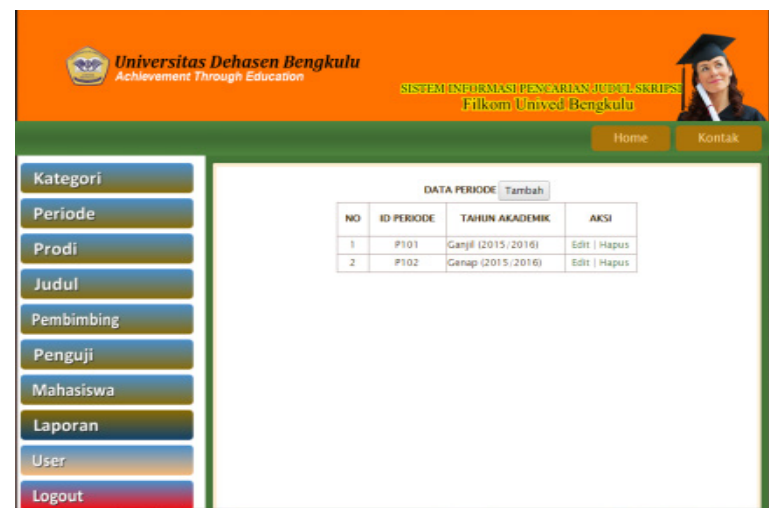

Gambar 4. Tampilan Data Periode

\section{E. Tampilan Menu Prodi}

Pada tampilan Menu Prodi terdapat menu untuk mengisi nama Program Studi (Prodi) dilingkungan Fakultas Ilmu Komputer Unived Bengkulu. Tampilan Menu Prodi seperti dapat dilihat pada Gambar 5. 


\section{F. Tampilan Menu Judul}

Pada tampilan menu Judul admin dapat memasukan judul-judul skripsi atau Laporan Tugas Akhir (LTA) mahasiswa. Tampilan menu judul dapat dilihat pada Gambar 6.

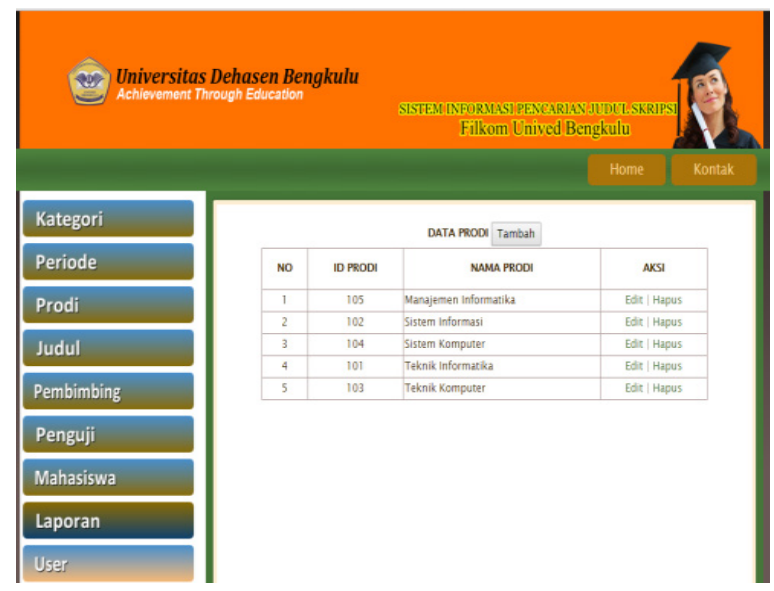

Gambar 5. Tampilan Menu Data Prodi

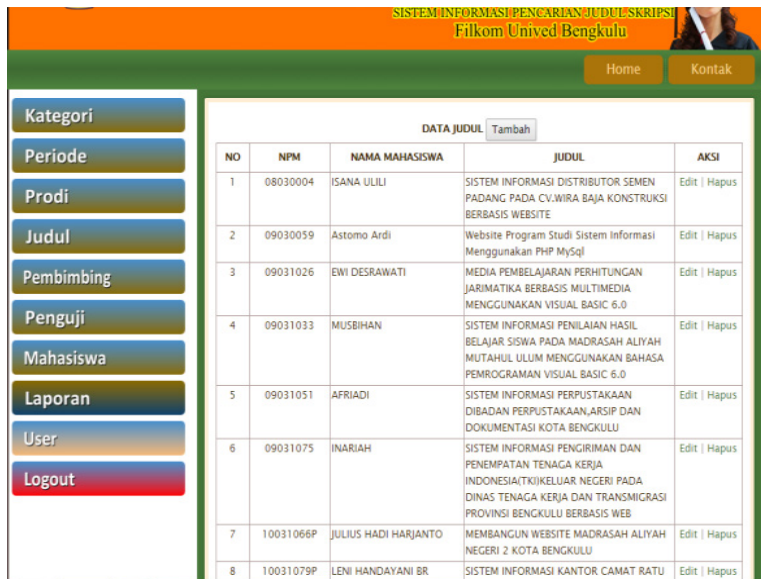

Gambar 6. Tampilan Menu Data Judul

\section{G. Tampilan Menu Pembimbing}

Pada tampilan menu Pembimbing terdapat tombol tambah untuk mengisi nama-nama dosen pembimbing skripsi. Tampilan menu Pembimbing dapat dilihat seperti pada Gambar 7.

\section{H. Tampilan Menu Penguji}

Pada tampilan menu Penguji terdapat isian nama-nama dosen penguji skripsi. Tampilan menu Penguji dapat dilihat pada Gambar 8.

\section{Tampilan Menu Mahasiswa}

Pada tampilan menu Mahasiswa terdapat ko- lom isian nama mahasiswa yang menulis LTA atau Skripsi. Tampilan menu Mahasiswa dapat dilihat seperti pada Gambar 9.

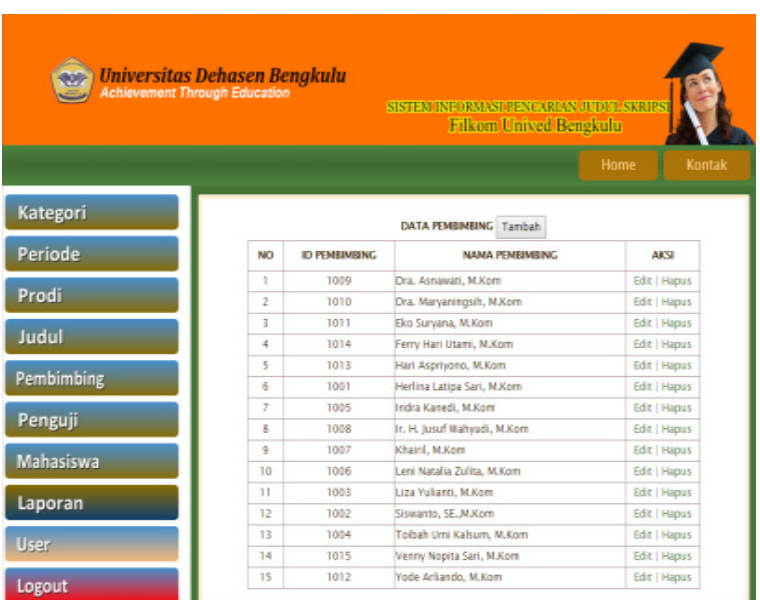

Gambar 7. Tampilan Menu Data Pembimbing

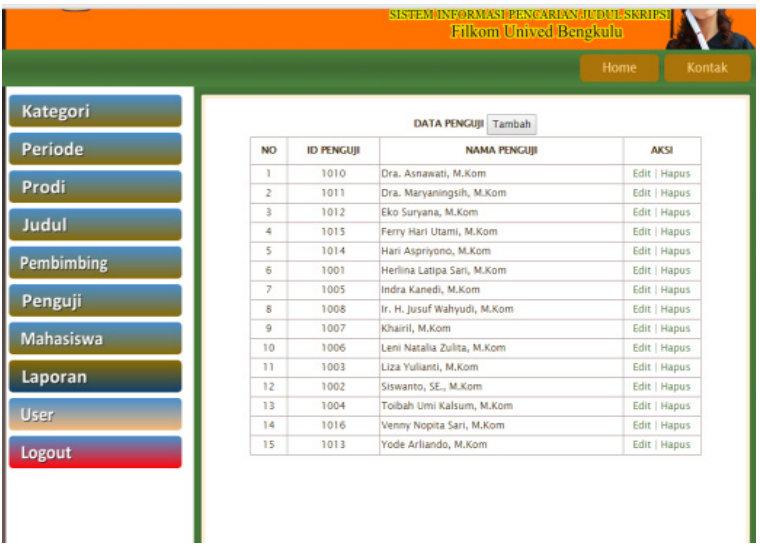

Gambar 8. Tampilan Menu Data Penguji

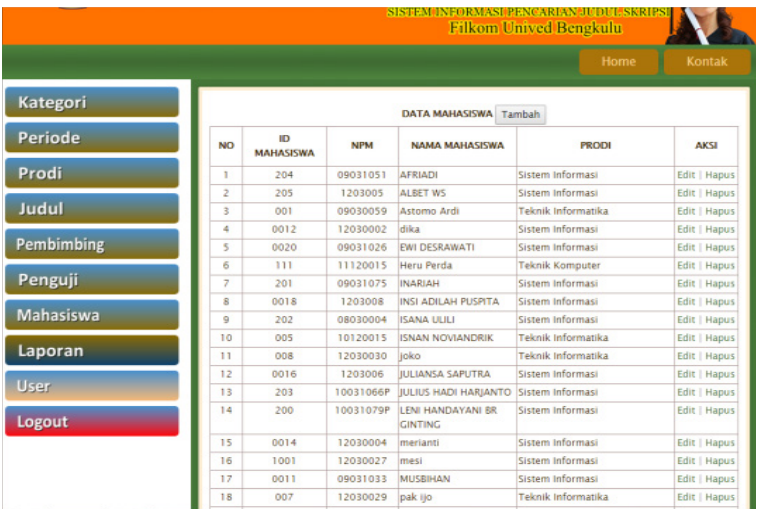

Gambar 9. Tampilan Menu Data Mahasiswa

\section{J. Tampilan Menu Laporan}

Pada tampilan menu Laporan terdapat output rekapitulasi judul-judul LTA \& Skripsi periode semester ganjil dan genap mahasiswa Fakul- 
tas Ilmu Komputer Unived Bengkulu. Tampilan menu Laporan seperti terlihat pada Gambar 10.

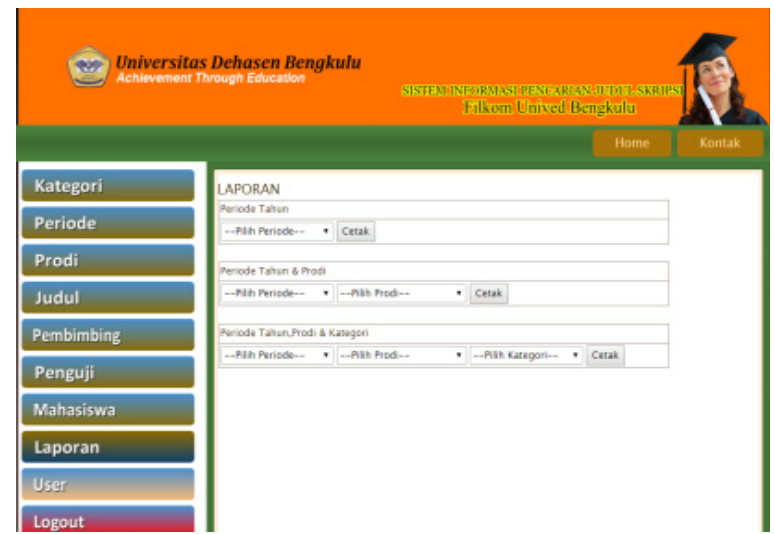

Gambar 10. Tampilan Menu Data Laporan

\section{K. Tampilan Menu User}

Pada menu User terdapat nama-nama user yang dapat mengelola aplikasi ini sesuai dengan levelnya, terdapat level admin, dosen dan prodi. Tampilan menu data user dapat dilihat seperti pada Gambar 11 .

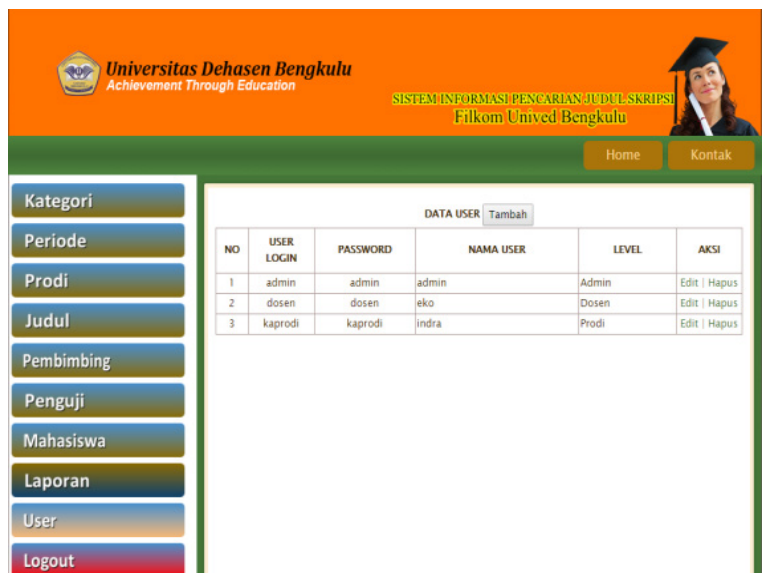

Gambar 11. Tampilan Menu Data User

\section{Tampilan Menu Input Data}

\section{1) Input Data Kategori}

Pada menu input data kategori admin dapat mengisi data Id Kategori dan Nama Kategori. Nama kategori diisi berdasarkan kategori judul skripsi mahasiswa. Tampilan menu input kategori dapat dilihat seperti pada Gambar 12.

\section{2) Input Data Periode}

Pada menu input data Periode dapat diisi de- ngan id kategori dan nama periode. Nama periode diisi dengan Ganjil dan Genap per-tahun sesuai dgn periode wisuda. Tampilan menu input data periode dapat dilihat pada Gambar 13.

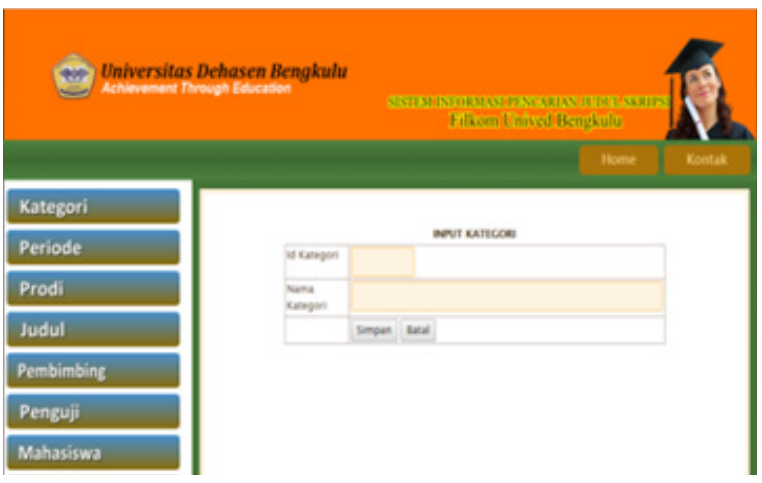

Gambar 12. Input Data Kategori

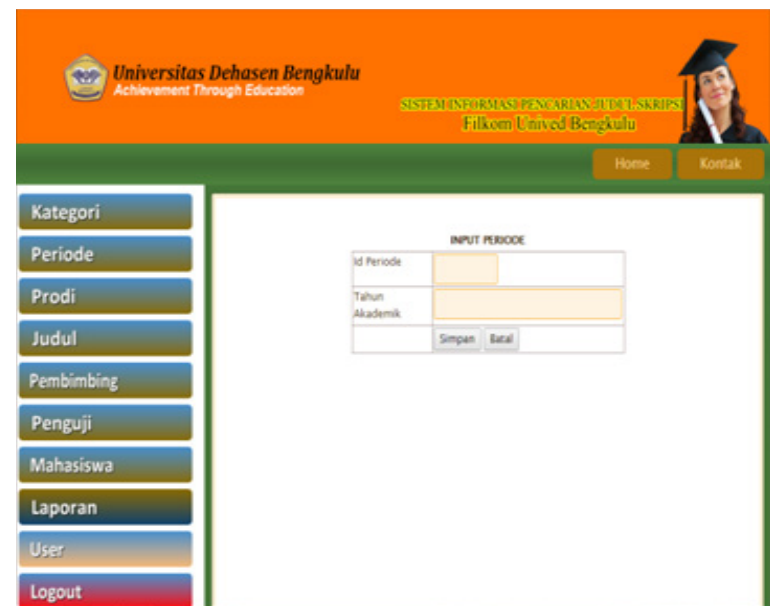

Gambar 13. Menu Input Data Periode

\section{3) Input Data Prodi}

Pada tampilan menu input prodi dapat diisi dengan id prodi dan nama Program Studi (Prodi) dilingkungan Unived Bengkulu. Tampilan menu input data prodi dapat dilihat pada Gambar 14.

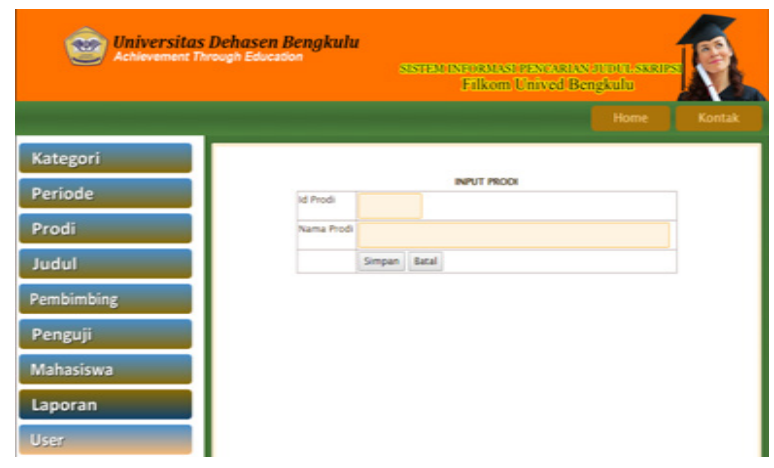

Gambar 14. Menu Input Data Prodi 


\section{4) Input Data Judul}

Pada input data judul user dapat mengisikan id mahasiswa, NPM, nama mahasiswa, judul, prodi, pembimbing dan penguji. Tampilan menu input data judul seperti terlihat pada Gambar 15.
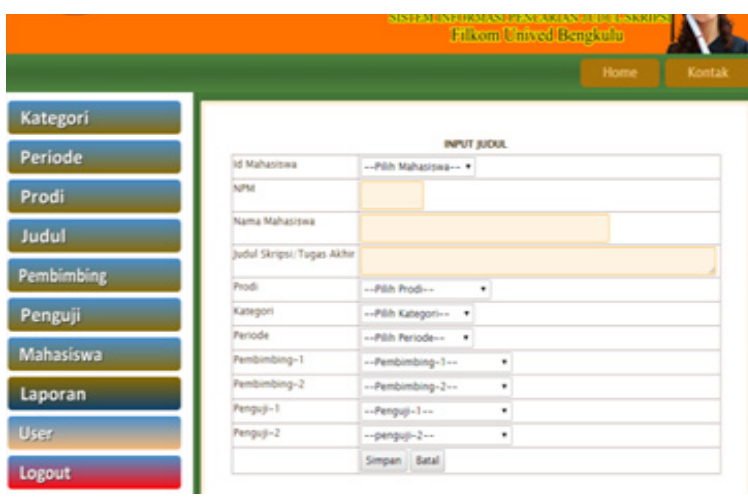

Gambar 15. Menu Input Data Judul

\section{5) Input Data Pembimbing}

Pada menu input data pembimbing user dapat mengisi id pembimbing dan nama pembimbing skripsi. Tampilan menu input pembimbing dapat dilihat pada Gambar 16.

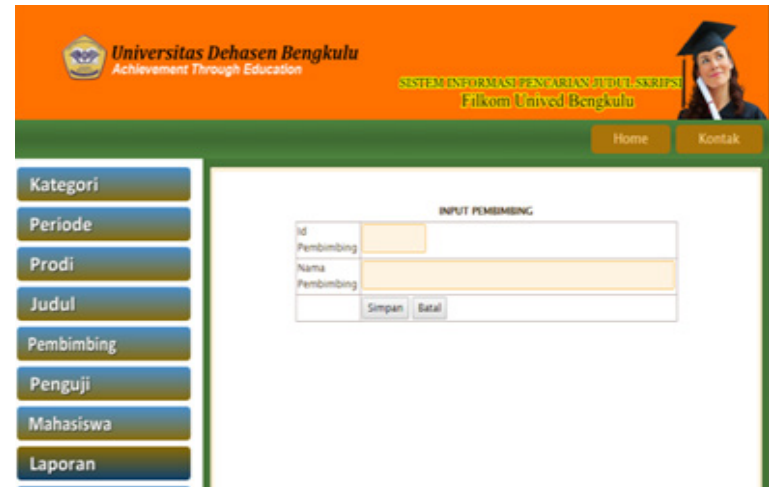

Gambar 16. Menu Input Data Pembimbing

\section{6) Input Data Penguji}

Pada menu input data penguji user mengisikan data penguji terdiri dari id penguji dan nama dosen penguji. Tampilan menu input penguji seperti pada Gambar 17.

\section{7) Input Data Mahasiswa}

Pada input data mahasiswa dapat di inputkan id mahasiswa, NPM, nama mahasiswa dan prodi. Tampilan menu input mahasiswa dapat dilihat pada Gambar 18.

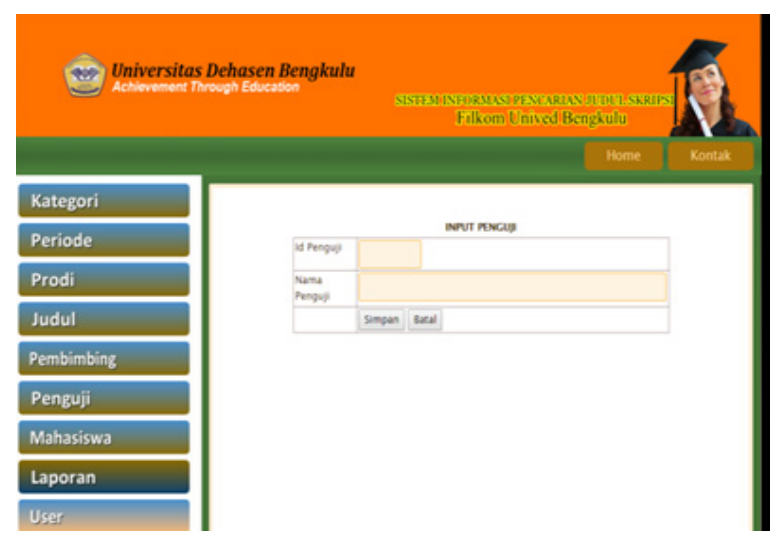

Gambar 17. Menu Input Data Penguji

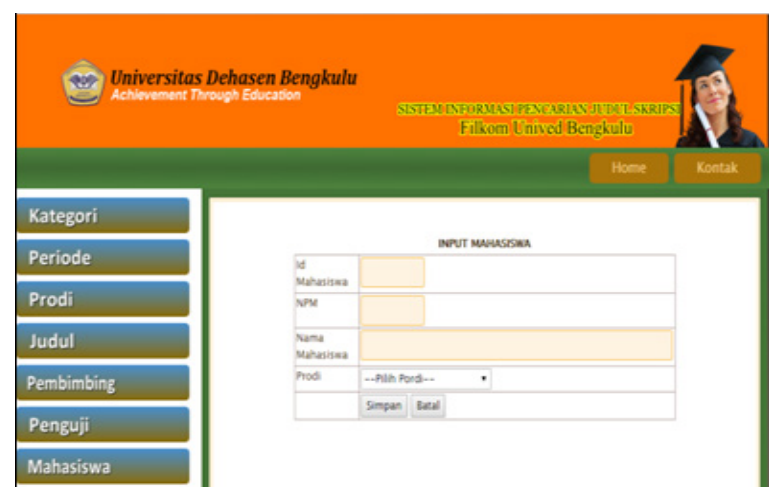

Gambar 18. Menu Input Data Mahasiswa

\section{Input Cetak Laporan}

Pada menu input laporan dapat dipilih jenis laporan sesuai dengan yang disediakan di aplikasi. Tampilan input data laporan dapat dilihat pada Gambar 19.

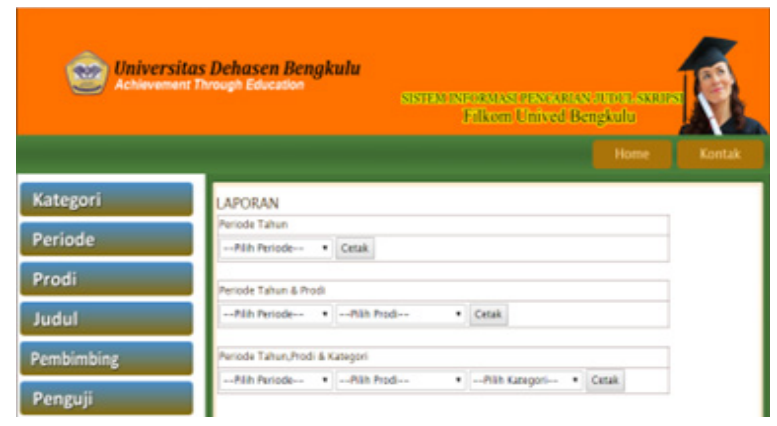

Gambar 19. Menu Input Cetak Laporan

\section{1) Menu Input Data User}

Pada menu input user dapat diisikan dengan nama user sesuai dengan pilihan level user. Tampilan menu input data user dapat dilihat pada Gambar 20. 


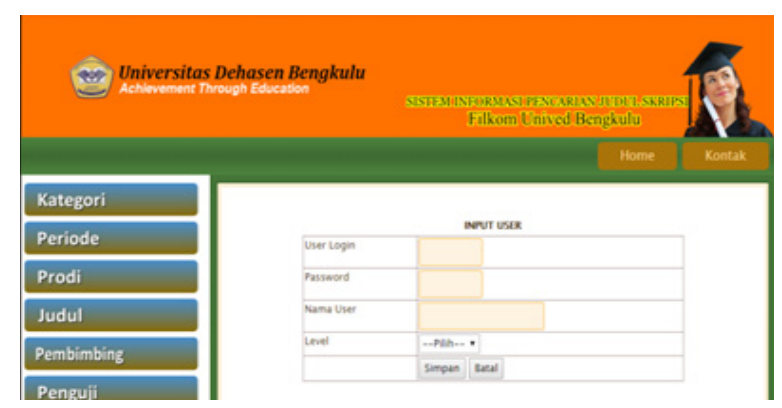

Gambar 20. Menu Input Data User

\section{PENUTUP}

\section{A. Kesimpulan}

Berikut kesimpulan yang dapat disampaikan hasil dari pemaparan penelitian.

1. Aplikasi ini dapat digunakan dengan baik sebagai salah satu sistem pencarian judul skripsi yang tujuannya untuk memudahkan mahasiswa dan program studi dalam mengelola judul skripsi yang ada selama ini dilingkungan Fakultas Ilmu Komputer Universitas Dehasen Bengkulu.

2. Aplikasi ini dapat dimanfaatkan oleh mahasiswa ketika akan mengajukan judul skripsi apakah judul yang akan diajukan sudah ada yang menggunakan atau belum sehingga dapat meminimalisir terjadinya judul skripsi yang sama.

\section{B. Saran}

Dari kesimpulan diatas, ada beberapa saran agar dapat menggunakan program aplikasi ini dengan maksimal.

1. Agar aplikasi ini dapat dimanfaatkan dengan maksimal maka dibutuhkan sosialisasi oleh program studi kepada mahasiswanya.

2. Aplikasi ini masih dapat dikembangkan seiring dengan berjalannya waktu, oleh karenanya diperlukan referensi lain yang mampu menjadikan aplikasi ini berkembang terus.

\section{DAFTAR PUSTAKA}

Herlambang, Soendoro, dan Harianto Tanuwijaya. 2005. Sistem Informasi: konsep, teknologi,dan manajemen. Graha Ilmu : Yogyakarta

Jogiyanto, (2005:34). Pengantar Sistem Informasi. Yogyakarta: Andi Publishing.

Kumorotomo (2010). Pengenalan Hardware, Andi Yogyakarta, 356 Halaman.

Ladjamudin (2005:62), Analisis dan Desain Sistem Informasi, Andi Yogyakarta

Nogroho (2004:40), Analisis dan Perancangan Sistem Informasi, Penerbit Informatika, Yogyakarta. 